\title{
Interaction of potential and effective entrepreneurial capabilities in adolescents: modeling youth entrepreneurship structure using structural equation modeling
}

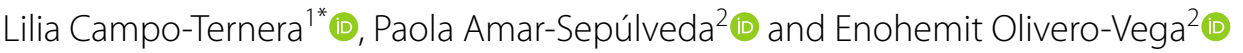

\author{
*Correspondence: \\ licampo@unisimonbolivar. \\ edu.co \\ ${ }^{1}$ Research and Social \\ Innovation Center, \\ Universidad Simón Bolívar, \\ Barranquilla, Colombia \\ Full list of author information \\ is available at the end of the \\ article
}

\begin{abstract}
This article emphasizes entrepreneurial skills in adolescents, in order to determine the relationship between entrepreneurial skills (dependent variable) and the key factors for their development: personal, social, and educational (independent variables). It has an empirical-analytical design which is explanatory in nature. After the design, validation, and application of the evaluation instrument, the estimation was carried out using Structural Equation Modeling (SEM). The results show great impact of potential entrepreneurial capacity on effective entrepreneurial capacity, determined by the direct effect of personal traits and life skills, the family as a moderating element, as well as the mediating role of entrepreneurship training processes. The complex nature of entrepreneurship is highlighted, which is influenced by multiple factors as possible boosters for the success of entrepreneurial initiatives.
\end{abstract}

Keywords: Entrepreneurship, Entrepreneurial skills, Personal attributes, Social skills, Entrepreneurship training

\section{Introduction}

Entrepreneurship is understood as the set of characteristics and traits of individuals that generate a unique behavior, which drives them to creative ideas and changes and to take risks and which allows them to achieve a differentiating or successful performance. Moreover, Clarysse et al. (2011) define this concept as the characteristics and traits that allow an individual to perceive, assimilate, and take advantage of opportunities that favor transformation and innovation actions of a differentiating and unique behavior.

Because entrepreneurial skills are a key element in the path toward sustainable development, their development in adolescent population should be considered beyond training for business generation and should be understood as a complex phenomenon integrating personal development with a transforming attitude and an innovative vision that allows them to actively participate in society until they can enter the labor market with the skills required to become successful. This can be achieved either through a self-employment initiative or as a formal employee, with the ability to recognize

(c) The Author(s) 2022. Open Access This article is licensed under a Creative Commons Attribution 40 International License, which permits use, sharing, adaptation, distribution and reproduction in any medium or format, as long as you give appropriate credit to the original author(s) and the source, provide a link to the Creative Commons licence, and indicate if changes were made. The images or other third party material in this article are included in the article's Creative Commons licence, unless indicated otherwise in a credit line to the material. If material is not included in the article's Creative Commons licence and your intended use is not permitted by statutory regulation or exceeds the permitted use, you will need to obtain permission directly from the copyright holder. To view a copy of this licence, visit http:// creativecommons.org/licenses/by/4.0/. 
opportunities and put these skills into practice to take advantage of them as a way to generate value to society by turning their ideas into real possibilities.

In this context, the main essence of these potential entrepreneurial capabilities allows an individual to detect, recognize, and absorb opportunities to be able to generate behavior oriented to the materialization of ideas in a real environment of economic development (Clarysse et al., 2011; Díaz-Casero et al., 2012; Shane \& Venkataraman, 2000; Tarrats-Pons et al., 2015) boosting their ability to perceive and analyze such initiatives for the exploitation of new ventures, with deep commitment that leads them to use all their resources to respond in a timely manner to the idea discovered and thus makes the entrepreneurial activity a reality, as pointed out by Cabana-Villca et al. (2013).

In addition to the above, there are key elements to strengthen entrepreneurial potential, such as personal traits, social skills, and attitudes toward risk (Álvarez \& Busenitz, 2001), which in turn strengthen the identification process to face opportunities within an environment by evaluating risks and situations of uncertainty (Koellinger et al., 2007). This construct has been proposed as a trend articulated by authors and researchers, such as Timmons (1994), who recognizes leadership, motivation to excel, creativity, self-reliance, and opportunity obsession as dominant factors of the entrepreneurial profile.

Meanwhile, Busenitz and Barney (1997) mention the ability to identify and face opportunities as an element of entrepreneurial profiles, a characteristic also mentioned by Lezana and Tonelli (1998) and Palich and Bagby (1995). Moreover, Eckhardt and Shane (2003), Shane and Venkataraman (2000), and Volery and Mazzarol (2015) highlight the ability to identify and choose the right opportunities as a key element of entrepreneurs. Thrane et al. (2016) stress the ability to learn as an important trait of the entrepreneur, whereas for Filion and Gilles (1996) and Zahra and Garvis (2000), an entrepreneur is a proactive person, with a vision of the future, has great passion and motivation, as well as the ability to evaluate risks and situations of uncertainty. Barba-Sánchez and Atienza-Sahuquillo (2011) agree with this and add that the ability to recognize and take advantage of opportunities is important. Other characteristics related to potential entrepreneurial skills are high levels of commitment, as stated by Loli et al. (2010) and Leite (2000), and, finally, Varela and Bedoya (2006) highlight the adaptability and vision of the future in the entrepreneur as the ability to perceive trends and foresee future events.

\section{Entrepreneurial skills and factors associated with their development}

The concept of potential and effective entrepreneurial skills has been based on the interaction of internal and external elements that play in the entrepreneur's actions. In this regard, Shapero and Sokol (1982) establish as determinants of entrepreneurial intention the perceived desirability, perceived feasibility, and behavior in risk situations; addressing the relationship of situational and sociocultural conditions that make an entrepreneurial event occur as a result of situational impulse on the person whose perceptions and values are in turn determined by their experiences and sociocultural representations, which is also supported by Soria-Barreto et al. (2016); Tarrats-Pons et al. (2015) and by Elfving et al. (2009).

Based on Shapero's ideas, Ajzen (1991) proposes the theory of planned behavior (TPB), which establishes as determinants of entrepreneurship the attitude toward oneself, a certain degree of social influence, and a degree of self-control over the results obtained. 
This is taken up by Soria-Barreto et al. (2016); Tarrats-Pons et al. (2015) and by Elfving et al. (2009).

Along the same lines, Krueger and Brazeal (1994) proposed an entrepreneurial potential model (EPM) where credibility plus entrepreneurial intention determines the potential capacity, which is converted into action by the occurrence of a triggering event, which can be both positive and negative. The ideas of Azjen (1991) and Shapero (1982) were considered to generate this model, and elements from both authors were integrated such as perceived viability and desirability; incorporating the notion of credibility, necessity, and viability of behavior, in this case, entrepreneurial behavior. Similarly, the concept of self-efficacy developed by Bandura (1986) and to which Davidson (1995) included skills, need, opportunity, values, and attitudes related to the entrepreneurial concept as such was also incorporated (Soria-Barreto et al., 2016).

Thus, potential and effective entrepreneurial capabilities will depend on personal subjective and/or social factors resulting from the interaction of cultural, familial, work related, and economic elements, which positively or negatively affect the way in which the person faces the possibility of entrepreneurship. Also, credibility plus entrepreneurial intention will determine the entrepreneurial potential that directly impacts entrepreneurial intention and also develops the ability to recognize a new opportunity (Clarysse et al., 2011; Durán-Aponte \& Arias-Gómez, 2016; Krueger \& Brazeal, 1994).

In general terms, while one strand of researchers tends to emphasize individual traits such as experience and opportunity recognition skills as critical explanations of entrepreneurial activity, other studies have predominantly focused on social environmental factors to explain entrepreneurial behavior. As Clarysse et al. (2011) argue that while the mainstream entrepreneurship literature attributes a central role to individual differences followed by social context in explaining the trend to become an entrepreneur, the ability to recognize opportunities is the determining variable in the concept of entrepreneurship, unlike Shane and Venkataraman (2000) who consider individual differences to be the most important element in becoming an entrepreneur.

Moreover, the systemic entrepreneurship theory proposed by Tarrats-Pons et al. (2015) integrates constructs related to training; personal variables; competencies and skills that are related to the knowledge acquired and the competencies developed, as opposed to the recognition of opportunities in their context and which can be positively or negatively influenced on entrepreneurial intention andare added to variables such as age, gender, family references, and socioeconomic profile.

Entrepreneurial skills in adolescents are a key factor in the economic growth of a country. Therefore, an education based on entrepreneurship favors the skills and knowledge required to generate entrepreneurial minds at early ages, focused on the business sector. Thus, Gómez (2019) states that the psychosocial profile of an entrepreneur based on the different scientific theories involves the identification of opportunities, the autonomous decision to explore these opportunities, the efforts to obtain the necessary resources, and the development of strategies to launch the entrepreneurship business.

Based on this approach, Sanchez et al. (2017) argue that the entrepreneur's profile is formed by a variety of influential factors that determine the effective capacity of the entrepreneurship. These personality traits are related to the support of society, the economy system, values, and culture. In other words, entrepreneurs are established when 
they have the potential capacity to possess personal factors related to self-efficiency, internal locus of control, and proactivity. In addition, they transcend to the sociocultural part when they have the attitude, control, and confidence to carry out the entrepreneurship. Meanwhile, Cabana-Villca et al. (2013), in their study, determined that the potential entrepreneurial capacity of a student depends on the entrepreneur's attributes, interpersonal skills, the ability to cope with risk situations, and an entrepreneurial attitude. The findings had greater relevance for entrepreneurial attitude and attributes, which accounted for $76 \%$. However, $74 \%$ of the students had potential entrepreneurial skills, whereas the percentage of students with effective entrepreneurial skills was only $16 \%$. This result highlights the importance of strengthening students' effective entrepreneurial skills through support strategies that allow the ideas of small entrepreneurs to materialize and thus continue contributing to the construction of a better future for new generations.

The conclusions of Mateus and Galeano (2015) are consistent with the foregoing, as they suggest the need to generate a new language related to entrepreneurship, understand the importance of its exhaustive development, and demonstrate how children and adolescents can develop entrepreneurial skills based on the socialization process in their family and school, which strengthen their autonomy, communication, leadership skills, and active participation in work teams.

In this regard, Krueger and Brazeal (1994) posit the importance of prior exposure to significant entrepreneurial role models and how the impact of role models operates through changes in perceptions of self-efficacy; cumulative exposure to different roles is also important; and family and social values influence beliefs about the viability of entrepreneurship as a vehicle for achievement. This is consistent with Boyd and Vozikis (1994), and Matthews and Moser (1996) affirm the importance of the family group in the process of developing a sense of self-efficacy, more evidently when entrepreneurial role models are found within the family nucleus, as it is an example of independence and how labor flexibility would positively impact the development of early entrepreneurial skills in the adolescent.

Furthermore, the Organization for Economic Co-operation and Development (OECD, 2005) suggests the importance of including entrepreneurship education (EE) from the early levels based on clear actions that offer real learning experiences and allow integrating theory with practice through active pedagogy (Gibb, 2005), linking technical knowledge with personal skills (Braidot et al., 2008), and always keeping a systemic and humanistic view of the individual in each of its psychological, cultural, and economic dimensions (Pereira, 2013).

The theoretical contributions described above show that although previous models developed on the subject of entrepreneurial skills have focused mainly on the adult population, we cannot ignore the fact that the creation of entrepreneurial subjects begins with the identification of those potentialities that are waiting to be developed from an early age, in order to generate a change in the medium- and long-term.

This research makes a theoretical contribution by trying to correct an existing gap, generated by prioritizing the study of entrepreneurial skills in the adult population or in university training processes, seeking with this study to answer the research 
question: How do potential and effective entrepreneurial skills interact in the adolescent population?

Thus, the aim of this article is to interpret how potential and effective entrepreneurial capabilities in adolescents are related to the key factors for their development: personal, social, and educational; and thus contribute to the literature by analyzing how personal traits are connected and complemented by social skills to form the basis of potential entrepreneurial capabilities, while at the same time delving into the degree of influence that sociocultural and educational factors have as mediating elements on the process of transforming entrepreneurial capabilities from potential into effective.

\section{Methods}

Design

An empirical-analytical, explanatory, non-experimental, transactional study based on correlational/causal designs, from the temporal perspective was prepared where the design is contemporary and bivariate; with respect to the amplitude and organization of the data. This research work sought to correlate entrepreneurial capacity (dependent variable) with the key factors for the development of entrepreneurial capabilities (independent variables).

\section{Participants}

The population and sample consisted of 1,579 Colombian adolescents attending secondary school in official institutions located in both urban and rural geographic areas; with an average age of 16 years, selected through a stratified random sampling method; 685 were female and 894 were male, with an age range between 13 and 19 years.

The following aspects were taken into account as inclusion criteria: being 13 years old at the time of instrument application and, in case of being of legal age, still studying in basic secondary education; being enrolled in an educational institution; currently studying in secondary education, with no differential approach or positive or negative discrimination related to physical features, age, sex, and sexual, ethnic, or religious preferences.

\section{Instruments of measurement}

To study entrepreneurial capabilities, an instrument was designed to assess personal and academic information, academic training, occupation of the family group, previous participation in entrepreneurship, or previous conceptions and entrepreneurship training (See Table 1). The instrument has a Likert scale to evaluate personal factors (See Table 2) and is made up of 39 items grouped into 5 personal factors, with six anchor adjectives, ranging from never to always. The rating of the items ranges from 1 to 6 , where 1 is the lowest score and 6 is the highest; with the possibility of a total attitude score of 234 points (See Table 3).

The Likert scale is designed to evaluate the organized entrepreneurial skills categories. Initially, it was given to six expert pairs for validation and then piloted for validation, with the participation of 257 adolescents, that is, $16.27 \%$ of the sample. 
Table 1 Theoretical contributions determining the development of entrepreneurial development

\begin{tabular}{|c|c|c|}
\hline Authors & Proposed theory & $\begin{array}{l}\text { Factors associated with the } \\
\text { development of entrepreneurial } \\
\text { skills }\end{array}$ \\
\hline Shapero and Sokol (1982) & $\begin{array}{l}\text { Determinants of entrepreneurial } \\
\text { intention }\end{array}$ & $\begin{array}{l}\text { Desirability } \\
\text { Perceived viability } \\
\text { Behavior in risk situations } \\
\text { Situational and sociocultural condi- } \\
\text { tions } \\
\text { Business events } \\
\text { Situational drivers } \\
\text { Perceptions, values, experiences }\end{array}$ \\
\hline Ajzen (1991) & Theory of planned behavior & $\begin{array}{l}\text { Attitude toward oneself } \\
\text { Social influence } \\
\text { Degree of Self-control over results } \\
\text { obtained }\end{array}$ \\
\hline Krueger and Brazael (1994) & Model for entrepreneurial potential & $\begin{array}{l}\text { Credibility } \\
\text { Feasibility of behavior } \\
\text { Entrepreneurial intention } \\
\text { Triggering event }\end{array}$ \\
\hline Tarrats-Pons et al. (2015) & Systemic model of entrepreneurship & $\begin{array}{l}\text { Training } \\
\text { Personal variables } \\
\text { Competencies, skills and } \mathrm{K} \\
\text { Recognition of opportunities in the } \\
\text { given context }\end{array}$ \\
\hline Clarysse et al. (2011) & & $\begin{array}{l}\text { The ability to recognize opportuni- } \\
\text { ties is the determining variable in the } \\
\text { concept of entrepreneurship }\end{array}$ \\
\hline Shane and Venkataraman (2000) & & $\begin{array}{l}\text { Individual differences are the most } \\
\text { important element in becoming an } \\
\text { entrepreneur }\end{array}$ \\
\hline
\end{tabular}

Source: Prepared by the authors

Table 2 Items distributed by components associated with personal characteristics and individual attributes related to entrepreneurial skills assessed in the instrument

\begin{tabular}{lll}
\hline Personal factor & Direct items & Reversed items \\
\hline Social skills & $4-5-8-11-13-37$ & \\
Attitude toward opportunities & $1-19-23-28-31-32$ & 36 \\
Cognitive skills & $3-6-9-22-27-35$ & $12-29-33$ \\
positive self-assessment and continuity & $14-15-16-18-20-24-25-30$ & \\
Coping skills & $2-10-17-26-38-39$ & $7-21-34$ \\
\hline
\end{tabular}

Source: Prepared by the authors

The six anchor adjectives were designed in even numbers in order to avoid the fact that the evaluated person is oriented to an intermediate value, thus reducing objectivity and precision in the evaluation process. Values 1,2 , and 3 show unfavorability toward the profile in question, while ratings 4,5 and 6 show favorability.

\section{Procedure and data processing}

After the collection and validation of information carried out in educational institutions, the methodology was identified for (I) variable operationalization to be used in the model to be proposed, based on the items or responses of the respondents, with 
Table 3 Full extent of questions asked for each of the constructs

\begin{tabular}{|c|c|c|}
\hline \multirow[t]{7}{*}{ Attitude toward opportunities } & CE_P_35 & $\begin{array}{l}\text { 35. I like to discover new opportunities } \\
\text { to break the routine }\end{array}$ \\
\hline & CE_P_47 & $\begin{array}{l}\text { 47. I consider the problems I face as } \\
\text { challenges }\end{array}$ \\
\hline & CE_P_54 & $\begin{array}{l}\text { 54. I think a lot about my options before } \\
\text { taking advantage of an opportunity }\end{array}$ \\
\hline & CE_P_43 & $\begin{array}{l}\text { 43. I make decisions with my future in } \\
\text { mind }\end{array}$ \\
\hline & CE_P_48 & $\begin{array}{l}48 . \text { I plan everything I do so that I can } \\
\text { achieve my future goals }\end{array}$ \\
\hline & CE_P_2 & $\begin{array}{l}\text { 2. I believe that I must take risks to } \\
\text { achieve my goals }\end{array}$ \\
\hline & CE_P_29 & $\begin{array}{l}29 . \text { I take responsibility when things do } \\
\text { not go as expected }\end{array}$ \\
\hline \multirow[t]{9}{*}{ Cognitive skills } & CE_P_34 & 34. I consider myself a creative person \\
\hline & CE_P_40 & $\begin{array}{l}\text { 40. I like challenges where I can use my } \\
\text { creativity and imagination }\end{array}$ \\
\hline & CE_P_45 & $\begin{array}{l}\text { 45. I prefer to use the most practical and } \\
\text { proven ways to do my tasks }\end{array}$ \\
\hline & CE_P_11 & $\begin{array}{l}\text { 11. I like the idea of experimenting with } \\
\text { new things, regardless of whether they } \\
\text { will be successful or not }\end{array}$ \\
\hline & CE_P_53 & $\begin{array}{l}\text { 53. I like to think of new ways to } \\
\text { improve existing things }\end{array}$ \\
\hline & CE_P_18 & $\begin{array}{l}18 . \text { I prefer traditional alternatives that } \\
\text { have already proved to have good } \\
\text { results }\end{array}$ \\
\hline & CE_P_6 & $\begin{array}{l}\text { 6. When in doubt, I analyze my thoughts } \\
\text { and evaluate them internally }\end{array}$ \\
\hline & CE_P_14 & $\begin{array}{l}\text { 14. I obtain as much information as } \\
\text { possible when it comes to a topic of } \\
\text { interest to me }\end{array}$ \\
\hline & CE_P_49 & $\begin{array}{l}\text { 49. I think it is not necessary to debate if } \\
\text { the whole group agrees }\end{array}$ \\
\hline \multirow[t]{8}{*}{ Locus of control } & CE_P_23 & $\begin{array}{l}\text { 23. I am full of energy when I am start- } \\
\text { ing a new challenge }\end{array}$ \\
\hline & CE_P_28 & $\begin{array}{l}28 . \text { I tend to feel motivated to achieve } \\
\text { the goals I set for myself }\end{array}$ \\
\hline & CE_P_30 & 30. I like to do things on my own \\
\hline & CE_P_38 & $\begin{array}{l}\text { 38. It is important for me to have } \\
\text { autonomy to get things done }\end{array}$ \\
\hline & CE_P_22 & $\begin{array}{l}\text { 22. I believe I have the right skills to } \\
\text { achieve my goals }\end{array}$ \\
\hline & CE_P_46 & 46. I believe I am good at what I do \\
\hline & CE_P_25 & $\begin{array}{l}\text { 25. Once I make a commitment, I do } \\
\text { everything in my power to keep it }\end{array}$ \\
\hline & CE_P_37 & $\begin{array}{l}\text { 37. I care about following through on } \\
\text { my commitments }\end{array}$ \\
\hline
\end{tabular}


Table 3 (continued)

\begin{tabular}{|c|c|c|}
\hline \multirow[t]{9}{*}{ Coping Skills } & CE_P_4 & $\begin{array}{l}\text { 4. I modify my behavior to carry out } \\
\text { strategies that make my job easier }\end{array}$ \\
\hline & CE_P_58 & $\begin{array}{l}\text { 58. I consider that I am able to accept } \\
\text { change easily }\end{array}$ \\
\hline & CE_P_12 & $\begin{array}{l}\text { 12. It took me a while before I accepted } \\
\text { changes in what had been planned }\end{array}$ \\
\hline & CE_P_31 & $\begin{array}{l}\text { 31. I prefer things to remain stable and } \\
\text { as they have always been }\end{array}$ \\
\hline & CE_P_15 & $\begin{array}{l}15 . \text { I find it easy to decide what is } \\
\text { necessary to achieve my goals at the } \\
\text { right time }\end{array}$ \\
\hline & CE_P_27 & $\begin{array}{l}\text { 27. I am able to solve problems and } \\
\text { make the right decisions at the right } \\
\text { time }\end{array}$ \\
\hline & CE_P_50 & $\begin{array}{l}\text { 50. When I have a problem, I can only } \\
\text { think of one way to solve it }\end{array}$ \\
\hline & CE_P_39 & $\begin{array}{l}\text { 39. I prefer to take the initiative rather } \\
\text { than being told what to do }\end{array}$ \\
\hline & CE_P_63 & $\begin{array}{l}63 . \text { I consider myself a person who takes } \\
\text { initiatives }\end{array}$ \\
\hline \multirow[t]{9}{*}{ Sociocultural Perception } & FSC_P_1 & $\begin{array}{l}\text { In my region, it is possible to achieve } \\
\text { individual success through one's own } \\
\text { personal efforts }\end{array}$ \\
\hline & FSC_P_2 & $\begin{array}{l}\text { The culture of my region fosters risk- } \\
\text { taking for the development of entrepre- } \\
\text { neurial ideas }\end{array}$ \\
\hline & FSC_P_3 & $\begin{array}{l}\text { The culture of my region fosters creativ- } \\
\text { ity and innovative ideas }\end{array}$ \\
\hline & FSC_P_4 & $\begin{array}{l}\text { The culture of my region makes it easy } \\
\text { to implement entrepreneurial ideas }\end{array}$ \\
\hline & FSC_P_5 & $\begin{array}{l}\text { Being an entrepreneur is a real way to } \\
\text { make money }\end{array}$ \\
\hline & FSC_P_6 & $\begin{array}{l}\text { Successful entrepreneurs have a high } \\
\text { level of status and respect in my com- } \\
\text { munity }\end{array}$ \\
\hline & FSC_P_7 & $\begin{array}{l}\text { The media reports on successful entre- } \\
\text { preneurs'cases }\end{array}$ \\
\hline & FSC_P_8 & $\begin{array}{l}\text { Entrepreneurs are achievers and suc- } \\
\text { cessful people }\end{array}$ \\
\hline & FSC_P_9 & $\begin{array}{l}\text { If someone sets their mind to it, they } \\
\text { can become a successful entrepreneur }\end{array}$ \\
\hline \multirow[t]{5}{*}{ Entrepreneurship Education } & $F_{-} P_{-} 1$ & $\begin{array}{l}\text { Education fosters the development of } \\
\text { entrepreneurial skills in young people }\end{array}$ \\
\hline & FF_P_2 & $\begin{array}{l}\text { This school offers adequate preparation } \\
\text { for the development of entrepreneurial } \\
\text { ideas }\end{array}$ \\
\hline & $F_{-} P_{-} 3$ & $\begin{array}{l}\text { Entrepreneurship education is part of } \\
\text { the contents developed in this school }\end{array}$ \\
\hline & $F_{-} P_{-} 4$ & $\begin{array}{l}\text { In this school, entrepreneurship educa- } \\
\text { tion has sufficient teaching aids and } \\
\text { resources }\end{array}$ \\
\hline & $F_{-} P_{-} 5$ & $\begin{array}{l}\text { The people in charge of entrepreneur- } \\
\text { ship education at this school have the } \\
\text { necessary training }\end{array}$ \\
\hline Family Factors & $\begin{array}{l}\text { FF_AF_1/2/3 } \\
\text { FF_FAG_1/2 }\end{array}$ & $\begin{array}{l}\text { Schooling of family unit } \\
\text { Occupation of family unit }\end{array}$ \\
\hline
\end{tabular}


Table 3 (continued)

Source: Prepared by the authors

the construction of composite indicators; and (II) modeling the structure of youth entrepreneurship, through a Structural Equation Model.

After completing the steps of developing a conceptual framework and selecting the indicators-items, Cronbach's Alpha was used to identify the suitability of items for grouping in a composite indicator to then perform a process of weighting the information and a principal components analysis (PCA) based on polychoric correlations, considering that the PCA expresses as a natural method of aggregating the sum of rankings, without presenting any obstacle in this research. As all items were in the same scale (Likert) and dimensionality was maintained, normalization was not necessary in order to use conventional PCA based on Pearson correlation coefficient.

Subsequently, in order to measure the effect and relevance of the elements associated with the characteristics of the family environment and potential entrepreneurial capacity on effective entrepreneurial capacity, as well as the mediating effect of sociocultural factors and entrepreneurship training, an econometric approach known as the Structural Equation Model (SEM) was used.

To develop the SEM, the validity and reliability of the measurement model was analyzed. Firstly, it was confirmed that the measurement indicators were correctly measured and secondly, the interactions between different constructs of the theoretical model were analyzed.

In this study, manifest variables will be understood as the following: locus of control, coping skills, attitude toward opportunities, cognitive skills, social skills, the questions asked to the respondents about their family environment, sociocultural factors, and participation in training sessions for entrepreneurs. On the other hand, the latent variables (constructs) will be as follows: Personal Traits, Life Skills, Sociocultural Factors, Entrepreneurship Training, Effective Entrepreneurship, and the second-order construct potential entrepreneurship.

The SmartPLS eoc software was used to perform the SEM.

\section{Results and discussion}

The results of the measurement model show that the constructs used have a high degree of reliability and corroborate the validity of the instrument designed.

Table 4 shows the descriptive statistics of the variables included in the modeling process and the conclusions of the factor analysis of the loadings of measurement variables for the first-order constructs. In this regard, the findings show that the indicators used for the creation of the variables used in the structural model are considered reliable, after the elimination of indicators that did not meet the evaluation criteria. Therefore, Table 5 shows the total scope of the questions asked for each of the constructs.

Based on the structural analysis of the interaction model of potential and effective entrepreneurial capabilities in adolescents, a positive direct effect of life skills of 0.305 and of personal traits of 0.716 on potential entrepreneurial capabilities was observed, with a $99 \%$ significance (See Table 6). 
Table 4 Results of the measurement model

\begin{tabular}{|c|c|c|c|c|}
\hline Indicators & $\begin{array}{l}\text { Factor loadings indicator } \\
\text { reliability }\end{array}$ & $\begin{array}{l}\text { Construct } \\
\text { reliability }\end{array}$ & Convergent validity & $\begin{array}{l}\text { Discriminant } \\
\text { validity }\end{array}$ \\
\hline \multicolumn{5}{|l|}{ Family factors } \\
\hline FF_AF_1 & $0.797^{* * *}$ & \multirow[t]{5}{*}{0.739} & \multirow[t]{5}{*}{0.397} & \multirow[t]{5}{*}{0.144} \\
\hline FF_AF_2 & $0.779 * * *$ & & & \\
\hline FF_AF_3 & $0.591^{* * *}$ & & & \\
\hline FF_FAG_1 & $0.392^{* * *}$ & & & \\
\hline FF_FAG_2 & $0.387^{* *}$ & & & \\
\hline \multicolumn{5}{|c|}{ Sociocultural perception } \\
\hline F_SC_1 & $0.501^{* * *}$ & \multirow[t]{5}{*}{0.700} & \multirow[t]{5}{*}{0.287} & \multirow[t]{5}{*}{0.332} \\
\hline F_SC_3 & $0.518^{* * *}$ & & & \\
\hline F_SC_5 & $0.509^{* * *}$ & & & \\
\hline F_SC_8 & $0.603^{* * *}$ & & & \\
\hline F_SC_9 & $0.644^{* * *}$ & & & \\
\hline \multicolumn{5}{|c|}{ Training for entrepreneurship training } \\
\hline F_E_1 & $0.760^{* * *}$ & \multirow[t]{4}{*}{0.815} & \multirow[t]{4}{*}{0.525} & \multirow[t]{4}{*}{0.187} \\
\hline F_E_2 & $0.702^{* * *}$ & & & \\
\hline F_E_3 & $0.766^{* * *}$ & & & \\
\hline F_E_5 & $0.664^{* * *}$ & & & \\
\hline \multicolumn{5}{|l|}{ Personal traits } \\
\hline A_C & $0.923^{* * *}$ & \multirow[t]{3}{*}{0.937} & \multirow[t]{3}{*}{0.831} & \multirow[t]{3}{*}{0.385} \\
\hline A_F_O & $0.919 * * *$ & & & \\
\hline$C_{-} E$ & $0.892^{* * *}$ & & & \\
\hline \multicolumn{5}{|l|}{ Life skills } \\
\hline H_S & $0.918^{* * *}$ & \multirow[t]{2}{*}{0.923} & \multirow[t]{2}{*}{0.856} & \multirow[t]{2}{*}{0.367} \\
\hline$P_{-} L$ & $0.931^{* * *}$ & & & \\
\hline \multicolumn{5}{|c|}{ Effective entrepreneurial capacity } \\
\hline CE_E & $1.000^{* * *}$ & & & 0.059 \\
\hline
\end{tabular}

Table 5 Total scope of the questions asked for each of the constructs

\begin{tabular}{|c|c|c|c|c|}
\hline Construct & $\begin{array}{l}\text { Factor loadings indicator } \\
\text { reliability }\end{array}$ & $\begin{array}{l}\text { Construct } \\
\text { reliability }\end{array}$ & $\begin{array}{l}\text { Convergent } \\
\text { validity }\end{array}$ & $\begin{array}{l}\text { Discriminant } \\
\text { validity }\end{array}$ \\
\hline \multicolumn{5}{|c|}{ Potential entrepreneurial capacity } \\
\hline Life skills & $0.305^{* * *}$ & & & \\
\hline Personal traits & $0.716^{* * *}$ & & & \\
\hline
\end{tabular}

The potential entrepreneurial capacity directly affects effective entrepreneurial capacity, positively and with a $95 \%$ significance, showing a direct effect with a coefficient equivalent to 0.321 . In turn, potential entrepreneurship has a positive direct effect of $99 \%$ significance on entrepreneurship training equivalent to 0.180 and on sociocultural perception of 0.321 . On the other hand, family factors show a direct effect of 0.107 on effective entrepreneurship with a $99 \%$ positive significance. Similarly, entrepreneurship training positively influences effective entrepreneurship, showing a direct effect of 0.128 on effective entrepreneurship, with a $99 \%$ significance. 
Table 6 Structural model

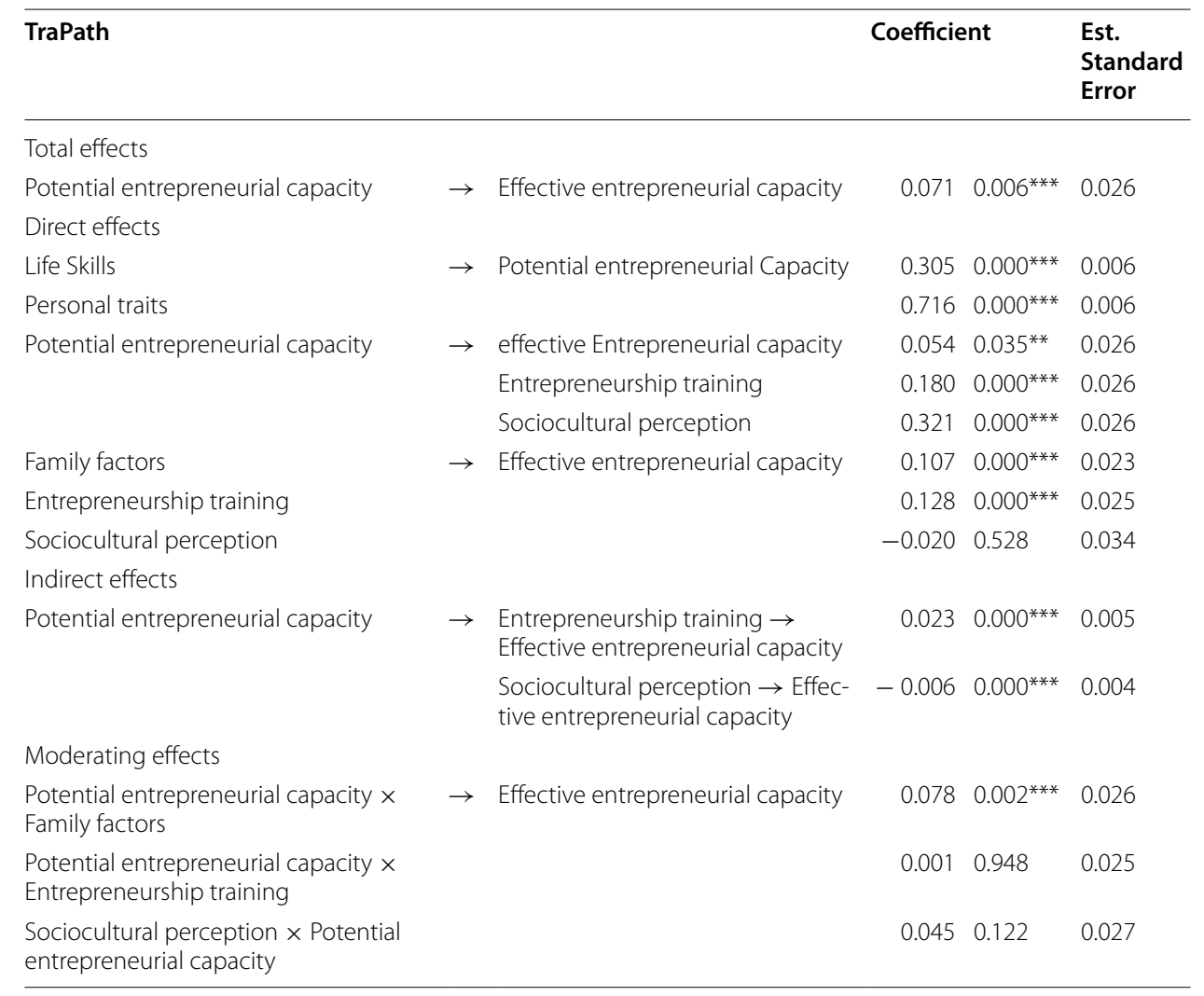

Significance $99 \% * * *, 95 \% * *, 90 \% *$

Source: Authors' calculations

Thus, the analysis of potential entrepreneurial capacity showed an indirect effect equivalent to 0.023 , of a positive nature, and $99 \%$ significance on entrepreneurship training and thus, on the effective entrepreneurial capacity (See Table 4).

In the case of the relationship between effective entrepreneurship, entrepreneurship training, and potential entrepreneurship, there is a mediation effect equivalent to 0.23 , which is a partial measurement, i.e., it is not the only thing that affects the relationship between potential and effective entrepreneurship, since there is a direct effect between them equivalent to 0.054 . This mediating effect shows that the direct effect of potential entrepreneurship on effective entrepreneurship is also positively affected by entrepreneurship training, significantly increasing the total effect between both constructs.

Conversely, there is no mediation by sociocultural perception on the relationship between potential and effective entrepreneurship, since sociocultural perception does not show a significant direct effect of sociocultural perception on effective entrepreneurship. However, there is a negative indirect effect of -0.006 of the way in which sociocultural conditions are perceived on the effect of potential entrepreneurship on effective entrepreneurship, showing that the way in which sociocultural factors are perceived decreases effective entrepreneurship in a non-significant way. 


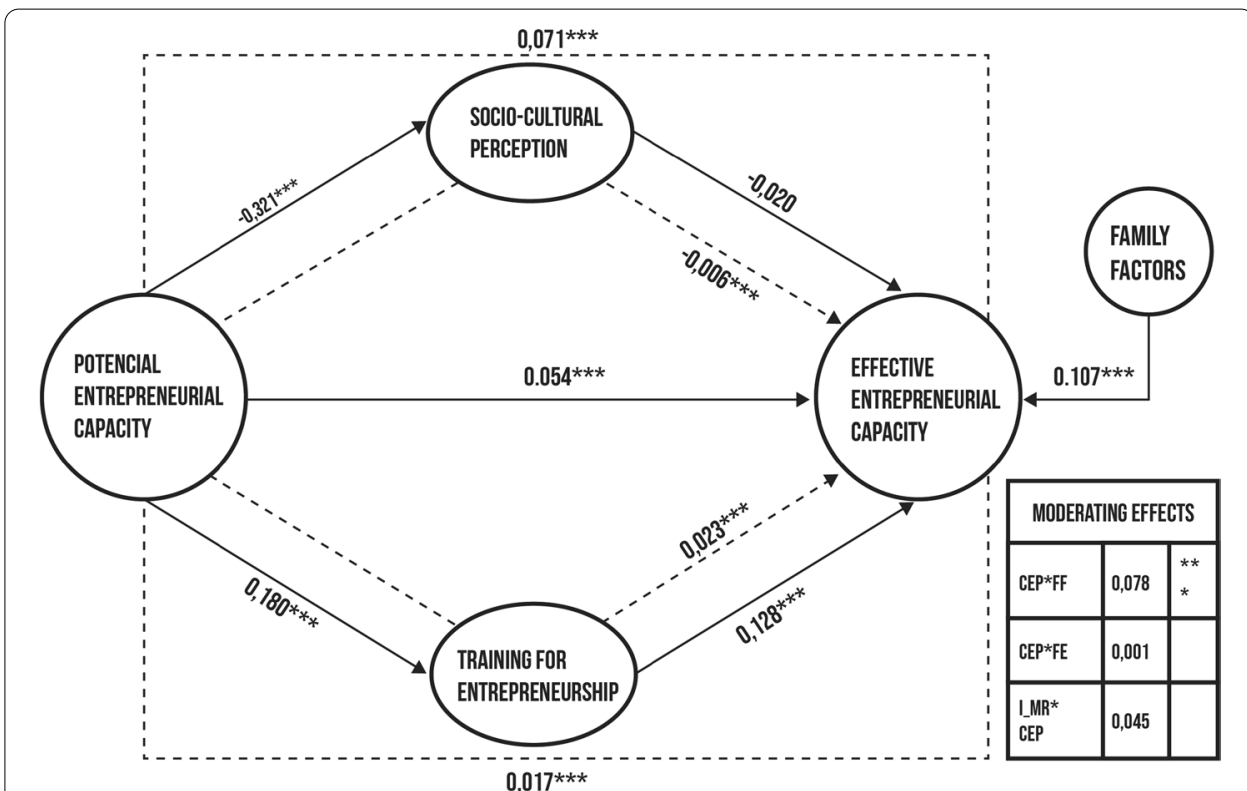

Fig. 1 Structural model specifying results. Significance $99 \%^{* * *}, 95 \% * *, 90 \% *$. Source: Prepared by the authors

Moreover, the positive direct effect of family factors on effective entrepreneurship is also evident, equivalent to 0.107 , with a $99 \%$ significance. At the same time, a moderating role of family factors on the interaction between potential and effective entrepreneurship is observed. This can be interpreted in terms of the fact that the more optimal the family conditions are, the stronger the positive difference on effective entrepreneurship will be.

As a model conclusion in terms of the main variables, the direct effect of the potential entrepreneurial capacity on the effective entrepreneurial capacity is 0.054 , while the indirect effect of the former on the latter is 0.023 , because both effects are positive in nature. The sum of these two direct and indirect effects is equivalent to 0.077 , to which the indirect effect of the sociocultural perception on the effective entrepreneurial capacity equivalent to -0.006 , as it is negative, must be subtracted.

Finally, there was a total effect equivalent to 0.071 of potential entrepreneurship on effective entrepreneurship, which is positive with a $99 \%$ significance (See Table 4).

Based on the structural analysis of the interaction model of potential and effective entrepreneurial capabilities in adolescents (Fig. 1), a direct and positive effect of personal factors composed of traits and life skills on potential entrepreneurial capabilities was observed, thus motivating them to take risks and recognize opportunities, to believe in themselves, and in the possibility of creating and transforming their ideas into successful projects. Therefore, the positive evaluation of capabilities is an important element in previous models of entrepreneurial capabilities, such as the contributions of Ajzen (1991); the EPM of Krueger and Brazeal (1994), and the systemic entrepreneurship theory raised by Tarrats-Pons et al. (2015).

Similarly, potential entrepreneurship positively affects the sociocultural perception and entrepreneurship training; in such a way that a high potential entrepreneurship capacity makes a more positive perception of the sociocultural factors and entrepreneurship 
training received in the educational institutions. In turn, entrepreneurship training showed a positive and direct effect on the effective entrepreneurial capacity, which is consistent with what has been proposed by several authors such as Blanchflower (2004); Bosma et al. (2008); and Naude et al. (2008). According to them, entrepreneurship training processes give rise to greater possibilities of generating entrepreneurial initiatives by increasing the willingness to discover opportunities and the potential for innovation.

A partial mediation effect is also observed between potential entrepreneurial capacity, entrepreneurship training, and entrepreneurial capacity. This mediating effect shows that entrepreneurship training processes favor the promotion of skills and capabilities, thus stimulating innovation potential and increasing the possibility of perceiving and evaluating their own potential capabilities and subsequently turn them into entrepreneurial intentions, which is consistent with the theoretical approaches on the importance of socialization spaces and teaching-learning processes associated with entrepreneurship training.

Moreover, family factors showed a direct effect on effective entrepreneurial capacity, also observing a role of family conditions that can generate a positive difference on effective entrepreneurial capacity. Since personal traits and life skills are complex characteristics developed gradually, and affecting the potential capacity for entrepreneurship, which in turn is enhanced by the training processes to determine how far the adolescent can go, entrepreneurship training ends up being a key element to achieve the implementation of entrepreneurial ideas, desires, or initiatives.

On the other hand, there is no mediation by sociocultural perception on the relationship between potential and effective entrepreneurship. However, the existence of a negative indirect effect shows that the way they perceive their sociocultural reality does not significantly reduce effective entrepreneurship.

Finally, we showed the direct and positive interaction between potential and effective entrepreneurial capacity. The latter is determined both by the basic personal capacity and by theoretical knowledge, but also by procedural and strategic knowledge acquired through training spaces.

\section{Conclusions}

In response to the question posed at the start of this work, we found that potential entrepreneurship has a direct and positive effect on effective entrepreneurship, an interaction which is mediated by the educational processes in which adolescents are immersed, and although there is no mediation by sociocultural perception, they are also determined by the surrounding family conditions. Regarding the question posed at the beginning of this article, it is concluded that there is a direct relationship between personal factors and life skills with respect to the potential entrepreneurial capacity of adolescents, showing a direct and positive effect of personal factors composed of traits and life skills on the potential entrepreneurial capacity. Similarly, the potential entrepreneurial capacity positively affects the sociocultural perception and entrepreneurship education. Thus, a high potential entrepreneurial capacity makes the sociocultural factors and the entrepreneurship education received in the educational institutions be perceived more positively.

Meanwhile, entrepreneurship education showed a partial mediation effect between potential entrepreneurial capacity and training for entrepreneurship, and capacity, also 
showing a direct and positive effect on effective entrepreneurial capacity. This mediating effect demonstrates how the training processes for entrepreneurship favor the development of skills and capabilities in adolescents, thus increasing the possibility to perceive and evaluate their own potential skills and turn them into effective capacity. This allows us to confirm the specific Hypothesis 2, which established that the relationship between potential entrepreneurial capacity and effective entrepreneurial capacity is mediated by the training process for entrepreneurship received by the adolescents.

However, the existence of a negative indirect effect shows that the way in which adolescents perceive their sociocultural factors does not significantly reduce their effective entrepreneurial capacity, and therefore the specific Hypothesis 3 is rejected. Finally, family factors showed a moderating effect on effective entrepreneurship. In this regard, the descriptive results of the family factors highlighted the importance of entrepreneurial role models between the nuclear and extended family, with the mother's education level and occupation being key, which shows how a mother interested in progressing academically or actively working becomes a positive role model for adolescents when it comes to seeing themselves as entrepreneurs. Thus, the importance of optimal family conditions on effective entrepreneurship is concluded, thereby confirming the specific Hypothesis 4.

Thus, the way in which adolescents perceive the entrepreneurship training received has a significant influence on effective entrepreneurship, while their perception of culture as a facilitator of the successful development of entrepreneurial initiatives does not significantly affect effective entrepreneurship.

Thus, the modeling of the youth entrepreneurship structure, by means of SEM highlights the complex nature of the interaction of potential and effective entrepreneurial capabilities in adolescents, showing the effect of multiple personal, cognitive, family, educational, and cultural factors.

Since the transition from a potential entrepreneurial capacity to an effective one is considered a long term process, the early development of an entrepreneurial culture that allows the development of potentialities and reduces the fear of failure, while constructively addressing the training processes, the sociocultural factors of the family system, and improving the adolescent's perception of his or her culture as favoring successful entrepreneurship, is key.

Based on the foregoing, the development of entrepreneurship skills in adolescents requires the generation of articulation processes between different actors: family members, educational institutions, the community in general, government entities, and the productive sector. In this regard, the entrepreneurship training processes go beyond the goal of stimulating the generation of business ideas, and should be oriented toward the development of skills for proposal generation and recognition of new opportunities, in order to define the relevant scenarios to develop projects, lead, and adapt work teams, through know-how spaces that stimulate their full potential.

It is precisely because of the complexity of this study subject matter that the research approach does not conclude at this point of analysis, giving rise to a new line of work. In this regard, the pending tasks are to expand the study to other regions of the country in order to study the influence of cultural differences and public policies on the development of entrepreneurial skills in adolescence. 
Thus, by way of conclusion, potential entrepreneurial capacity has a direct and positive effect on effective entrepreneurial capacity, an interaction that is mediated by the education processes in which adolescents are immersed, although there is no mediation by perception. More in-depth research is needed to generate more specific conclusions for the case of the population at this stage of the life cycle because it is striking that while adolescents consider the culture favorable for entrepreneurship, the perception that the actions and strategies implemented are aimed at adult entrepreneurs and that it is not something that favors them because of their age would end up demotivating them. Similarly, it is important to study the development of potential entrepreneurial skills in childhood and pre-adolescence as these are key stages for the personal and social development of human beings.

It is interesting to define the profiles of production projects considering the specific features of the economic dynamics in different regions, which would allow analyzing the sociocultural imaginaries on the economic categories required to promote a development model articulated with the productive potential of the territories that make up the sub-regions in the department of Atlántico.

Similarly, it is of interest to complement this first approach with technological tools that facilitate an approach to the adolescent population with a view to developing their potential, which in turn will become sources for future research. The results should also be submitted to the competent authorities in order to establish alliances with the entities responsible for the creation of public policy.

\footnotetext{
Abbreviations

SEM: Structural equation modeling; PCA: Principal component analysis; CEP: Potential entrepreneurial capabilities; FF: Family factors; FE: Entrepreneurship training.
}

\section{Acknowledgements}

We are very grateful to the Universidad Simón Bolívar for providing excellent conditions for the development of this study. This article is a product of the doctoral research model for the development of entrepreneurial skills in adolescents from 13 to 19 years old. Case of the Department of Atlántico.

\section{Authors' contributions}

LC has developed the model and wrote the original draft. While PA supported the construction of the original draft and EO helped during technical problems with the manuscript. All authors read and approved the final manuscript.

\section{Authors' information}

Campo-Ternera, Lilia: Psychologist, PhD in Administration. Master in Psychology. Specialist in Clinical Psychology. Educational, and Social Synapse Research Group. Research and Social Innovation Center, Simón Bolívar University, School of Law and Social Sciences, Barranquilla, Colombia. Orcid 0000-0002-1472-0362 Email: licampo@unisimonbolivar.edu.co. Amar-Sepúlveda, Paola: PhD in Industrial Engineering with emphasis on innovation and knowledge management, Vice-Director of Research and Innovation, Research Group Innovation and Entrepreneurship Management. Vice-481 Director of Research, Extension, and Innovation, Universidad Simón Bolívar, Barranquilla, Colombia. Orcid: 0000-00017346-2589 Colombia. Email: pamar@unisimonbolivar.edu.co.

Olivero-Vega, Enohemit: PhD in Administration, Master in Business Administration and Innovation, Universidad Simón Bolívar. Accounting Thinking and International Management Research Group. Universidad Simón Bolívar, School of Business and Administration, Barranquilla, Colombia. Orcid: 0000-0002-3146-462. Email: eolivero@unisimonbolivar.edu.co.

\section{Funding}

This research did not receive external funding.

Availability of data and materials

The data used in the framework of this research, which were analyzed, are available upon reasonable request.

\section{Declarations}

Competing interests

The authors have no conflicts of interest. 


\section{Author details}

${ }^{1}$ Research and Social Innovation Center, Universidad Simón Bolívar, Barranquilla, Colombia. ${ }^{2}$ Faculty of Administration and Business, Universidad Simón Bolívar, Barranquilla, Colombia.

Received: 14 May 2021 Accepted: 12 January 2022

Published online: 08 February 2022

\section{References}

Ajzen, I. (1991). The theory of planned behavior. Organizational Behavior and Human Decision Processes, 50(2), 179-211. https://doi.org/10.1016/0749-5978(91)90020-T

Álvarez, S., \& Busenitz, L. (2001). The entrepreneurship of resource-based theory. Journal of Management, 27, 755-775. https://doi.org/10.1177/014920630102700609

Bandura, A. (1986). The social foundations of thought and action. Prentice Hall.

Barba-Sánchez, V., \& Atienza-Sahuquillo, C. (2011). Reasons to create a new venture: a determinant of entrepreneurial profiles. African Journal of Business Management, 5(28), 11497-11504. https://doi.org/10.5897/AJBM11.1131

Blanchflower, D. (2004). Self-employment: More may not be better (NBER Working Paper No.10286, February). Cambridge: National Bureau of Economic Research. https://doi.org/10.3386/w10286

Bosma, N., Jones, K., Autio, E., Levie, J. (2008). Global Entrepreneurship Monitor: 2007. Executive Report. Londres: London Business School. Recuperado el 7 de mayo de 2018 de: https://www.babson.edu/Academics/centers/ blank-center/global-research/gem/Documents/gem-2007-executive-report.pdf

Boyd, N., \& Vozikis, G. (1994). The influence of self-efficacy on the development of entrepreneurial intentions and actions. Entrepreneurship Theory and Practice. https://doi.org/10.1177/104225879401800404

Braidot, N. B., Chiodi, F., Gonzales Pedraza, J., César, R. (2008). Fomento de las capacidades emprendedoras en estudiantes avanzados de Ingeniería Industrial de UNICEN. Experiencia piloto. Buenos aires. Universidad Nacional de Gral. Sarmiento. Argentina. Recuperado el 9 de abril de 2017 de:https://www.researchgate.net/profile/Gonzalez Pedraza/publication/228363020_Fomento_de_las_capacidades_emprendedoras_en_estudiantes_avanzados_ de_Ingenieria_Industrial_de_UNICEN/links/09e4150d0c67e0d225000000.pdf

Busenitz, L., \& Barney, J. (1997). Differences between entrepreneur and manager in large organization: biases and heuristic in strategic decision-making. Journal Business Venturing, 12, 9-30. https://doi.org/10.1016/S08839026(96)00003-1

Cabana-Villca R, Cortes-Castillo I, Plaza-Pasten D, Castillo-Vergara M, Alvarez-Marin A. Análisis de Las Capacidades Emprendedoras Potenciales y Efectivas en Alumnos de Centros de Educación Superior. J Technol Manag Innov. 2013;8(1):65-75. [fecha de Consulta 31 de Enero de 2022]. Disponible en: https://www.redalyc.org/articulo.oa?id= 84725699007

Clarysse, B., Tartari, V., \& Salter, A. (2011). The impact of entrepreneurial capacity, experience and organizational support on academic entrepreneurship. Research Policy, 40, 1084-1093. https://doi.org/10.1016/j.respol.2011.05.010

Díaz- Casero, J., Hernández- Mogollón, R., \& Roldan, J. (2012). A structural model of the antecedents to entrepreneurial capacity. International Small Business Journal, 30(8), 850-872. https://doi.org/10.1177/0266242610385263

Durán-Aponte, E., \& Arias-Gómez, D. (2016). Actitud emprendedora y estilos emocionales. Contribuciones para el diseño de la formación de futuros emprendedores. Rev Gestión De La Educación, 6(2), 83-102. https://doi.org/10. $15517 /$ rge.v1i2.25490

Eckhardt, J., \& Shane, S. (2003). Opportunities and entrepreneurship. Journal of Management, 29(3), 333-349. https:// doi.org/10.1177/014920630302900304

Elfving, J., Brännback, M., \& Carsrud, A. (2009). Toward a contextual model of entrepreneurial intentions. In A. L. Carsrud \& M. Brännback (Eds.), Understanding the Entrepreneurial Mind, 23 International Studies in Entrepreneurship 24. Springer Science + Business Media.

Fernández-Mesa, A., Alegre-Vidal, J., \& Chiva-Gómez, R. (2012). Orientación emprendedora, capacidad de aprendizaje organizativo y DeSESpeño innovador. Journal of Technology Management \& Innovation, 7(2), 157-170. https://doi. org/10.4067/S0718-27242012000200013

Filion, J., \& Gilles, R. (1996). Escuela de Altos Estudios Comerciales (HEC). Librería Universitaria.

Gibb, A. (2005). Creating the entrepreneurial university worldwide. ¿Do we need a wholly different mode of Entrepreneurship?, ponencia presentada en la Cuarta Conferencia de Investigación en Entrepreneurship en Latinoamérica, realizada en Cali, Colombia. Recuperado el 2 de abril de 2016, de: https://www.researchgate.net/publication/ 238743686_CREATING_THE_ENTREPRENEURIAL_UNIVERSITY_WORLDWIDE_DO_WE_NEED_A_WHOLLY_DIFFE RENT_MODEL_OF_ENTREPRENEURSHIP_2

Gómez Daza KS. Perfil psicosocial de la persona emprendedora (Tesis de pregrado). 2019. Recuperado de: http://hdl. handle.net/20.500.12494/13383

Koellinger, P. D., Minniti, M., \& Schade, C. (2007). Seeing the world with different. Oxford Bulletin of Economics and Statistics. https://doi.org/10.1111/j.1468-0084.2011.00689.x

Krueger, N. F., \& Brazeal, D. V. (1994). Entrepreneurial potential and potential entrepreneurs. Entrepreneurship Theory and Practice, 18, 91-104. https://doi.org/10.1177/104225879401800307

Leite, E. (2000). O Fenómeno do Emprendedorismo (2a ed.). Edicoes Bagaco.

Lezana, A. G. R., Tonelli, A. O. (1998). Comportamento do Empreendedor. In: MORI, F. Empreender: identificando, avaliando e planejando um novo negócio. Florianópolis: Escola de novos empreendedores

Loli, A., Dextre, E., Del Carpio, J., \& La Jara, E. (2010). Actitudes de creatividad y emprendimiento en estudiantes de la universidad nacional de ingeniería y su relación con algunas variables socio demográficas. Revista De Investigación En Psicología, 13(2), 139-151. https://doi.org/10.15381/rinvp.v13i2.3722 
Mateus, C., Galeano, P. (2015). Emprendimiento infantil—Modalidad Educación Empresarial en Primaria, Secundaria y Pre-escolar. En: La construcción de cultura emprendedora y empresarial un reto para América Latina en el siglo XXI: Memorias del 3er Congreso Internacional de Emprendimiento. Recuperado el 3 de Abril de 2016, http:// www.umariana.edu.co/ojs-editorial/index.php/libroseditorialunimar/article/view/628/554

Matthews, H., \& Moser, S. B. (1996). A longitudinal investigation of the impact of family background and gender on interest in small firm ownership. Journal of Small Business Management, 34, 29-43.

Naude, W., Gries, T., Wood, E., \& Meintjies, A. (2008). Regional determinants of entrepreneurial startups in a developing country. Entrepreneurship \& Regional Development, 20(2), 111-124. https://doi.org/10.1080/08985620701631498

OCDE. (2005). Principios y buenas prácticas para la concienciación y Educación Financiera, Recuperado el 25 de septiembre de 2015 en: http://www.bde.es/webbde/es/secciones/prensa/EdU_Financiera_final.pdf

Palich, L., \& Bagby, D. (1995). Using cognitive theory to explain entrepreneurial risk-taking: challenging conventional wisdom. Journal of Business Venturing, 10, 425-438. https://doi.org/10.1016/0883-9026(95)00082-J

Pereira, F. (2013). Reflexión sobre algunas características del espíritu emprendedor Colombiano. Econ Gest Desarro, 19(26), 9-26.

Sanchez JC, Ward A, Hernández B, Florez J. Educación emprendedora: estado del arte. Propósitos y Representaciones. 2017;5(2):401-73. https://doi.org/10.20511/pyr2017.v5n2.190.

Shane, S., \& Venkataraman, S. (2000). The promise of entrepreneurship as a field of research. Academy of Management Review, 25(1), 217-226. https://doi.org/10.5465/amr.2000.2791611

Shapero, A., \& Sokol, L. (1982). The social dimensions of entrepreneurship. In C. Kent, L. Sexton, \& K. Vesper (Eds.), Encylopedia of entrepreneurship (pp. 72-90). Prentice Hall.

Soria-Barreto, K., Zuniga-Jara, S., \& Ruiz-Campo, S. (2016). Educación e Intención Emprendedora en Estudiantes Universitarios: Un Caso de Estudio. Formación Universitaria, 9(1), 25-34. https://doi.org/10.4067/S0718-50062 016000100004

Tarrats-Pons, E., Mussons Torras, M., \& Ferràs Hernández, X. (2015). Del modelo del evento emprendedor al modelo sistémico de emprendimiento. 3C Empresa, 22(4), 124-135. https://doi.org/10.17993/3cemp.2015.040122.124-135

Thrane, C., Blenker, P., Korsgaard, S., \& Neergaard, H. (2016). The promise of entrepreneurship education: reconceptualizing the individual-opportunity nexus as a conceptual framework for entrepreneurship education. International Small Business Journal, 34(7), 905-924. https://doi.org/10.1177/0266242616638422

Timmons, J. A. (1994). New venture creation: entrepreneurship for the 21st century. Irwin.

Van der Sluis, J., Van Praag, M., \& Vijverberg, W. (2008). Education and entrepreneurship selection and performance: a review of the empirical literature. Journal of Economic Surveys, 22(5), 795-841. https://doi.org/10.1111/j.1467-6419. 2008.00550.x

Varela, R., \& Bedoya, O. (2006). modelo conceptual de desarrollo empresarial basado en competencias. Estudios Gerenciales, 22(100), 21-47. https://doi.org/10.18046/J.ESTGER.2006.198

Volery, T., \& Mazzarol, T. (2015). The evolution of the small business and entrepreneurship field: a bibliometric investigation of articles published in the International Small Business Journal. International Small Business Journal, 33(4), 374-396. https://doi.org/10.1177/0266242613516139

Weber, E. U., \& Milliman, R. A. (1997). Perceived risk attitudes: relating risk perception to risky choice. Management Science, $43,123-144$.

Zahra, S. A., \& Garvis, D. M. (2000). International corporate entrepreneurship and firm performance: the moderating effect of international environmental hostility. Journal of Business Venturing, 15(5-6), 469-492.

\section{Publisher's Note}

Springer Nature remains neutral with regard to jurisdictional claims in published maps and institutional affiliations.

\section{Submit your manuscript to a SpringerOpen ${ }^{\circ}$ journal and benefit from:}

- Convenient online submission

- Rigorous peer review

- Open access: articles freely available online

- High visibility within the field

Retaining the copyright to your article

Submit your next manuscript at $\boldsymbol{\nabla}$ springeropen.com 